\title{
Kierkegaard and Marx: Concurrences for a More Harmonious Life
}

\author{
Humberto Ortega-Villaseñor ${ }^{1}$ \\ Universidad de Guadalajara, Mexico
}

\begin{abstract}
These are dark days in Europe, in both developed and developing countries in the Western world. Our human condition and our survival as a species are endangered, under attack from multiples fronts (economic, political, social, moral, among others). The neoliberalism and free trade of the last 40 years have proven to be less than effective in achieving the type of development that brings benefits, equity and sustainability to the populations that live in the region. Far from it, this development model has fostered social injustice, an unprecedented polarization of processes, growing concentrations of wealth, political and financial power in the hands of the very few, and above all, a monopolistic power wielded by a tiny elite over a wide range of activities that affect the fate of millions of human beings. We believe that a review of the ideas and the cross pollination that connects the thinkers that have inspired this year's conference-- Søren Kierkegaard and Karl Marx - can serve to set up a complex critical scaffolding for understanding the tendencies that underlie these developments, estimating their historical weight and characterizing their neo-totalitarian or transpersonal ramifications for the 21 st century. In fact, we contend that in an extensive and profound sense, the critique that Kierkegaard made of his times (1846) with regard to the bourgeois Christian world comes ironically close to the Marxist critique of the bourgeois capitalist world (1847). This represents a relevant convergence that can shed light on the future consequences of current developments and help to find feasible solutions for preventing or counteracting their negative impact on the majority over the medium and long terms.
\end{abstract}

Keywords: Christianity, convergences, elites, historical materialism, neoliberalism, neo-totalitarianism.

If we want to heal our fractured and unstable world, we need to change course - and fast.

Jason Hickel, Goldsmiths, University of London, (Oxfam GB for Oxfam International, 2018, p. 8)

If one thinks about it, forty or fifty years ago it would have seemed highly unlikely that Marxism and Christianity would find common ground in Europe, given the political deterioration of Marxism and the social marginalization of Christianity in that part of the world (Jeffrey, 2011). More recently, however, a certain type of Marxist critique of institutions has been voiced by traditional liberals and Christians of the most radically orthodox intellectual culture (from the

${ }^{1}$ Corresponding Author E-Mail: huorvi@gmail.com 
Biblical point of view), especially in Great Britain, Canada and the United States (Jeffrey, 2011; Dussel, 2015; Dussel, 2016; Dorrien, 2018; Rivera, 2019). What is behind this? Perhaps the obscene levels of income that accrue to a tiny minority compared to the earnings of billions of their fellow human beings - a disparity that grows wider by the day, as disclosed in a dramatic report published by OXFAM in January of 2018:

Last year saw the biggest increase in billionaires in history, one more every two days. Billionaires saw their wealth increase by \$762bn in 12 months. This huge increase could have ended global extreme poverty seven times over. $82 \%$ of all wealth created in the last year went to the top $1 \%$, while the bottom $50 \%$ saw no increase at all. Dangerous, poorly paid work for the many is supporting extreme wealth for the few. Women are in the worst work, and almost all the super-rich are men. Governments must create a more equal society by prioritizing ordinary workers and small-scale food producers instead of the rich and powerful (2018, p.2).

This yawning inequality necessarily gives rise to an unprecedented and accelerating dehumanization that is engulfing an enormous mosaic of activities. This justifies our discernment of the meaning of this phenomenon, and what we consider to be an emerging Marxist and Christian critique that could prove to be valuable. We do so with a cultural approach that might appear somewhat eccentric, drawing on Mesoamerican traditions as well as a peripheral academic field where I have worked: interdisciplinarity. Ideas are taken from humanistic disciplines that are not restricted to Theology and Philosophy, the intention being to open the door to other fields of knowledge.

I believe that Kierkegaard and Marx take stances that are equidistant from Hegel's dialectic, but on opposite sides (Aroosi, 2018). On the one hand, Marx (1981), turns Hegel's dialectical structure around in order to explain and resolve the stages of his historical materialism, while Kierkegaard (2009a), builds a critique of the Christian world of his time (the mid-19th century) using Ethics as the guiding principle of the individual's inner life and decisions - being ethics superior and opposed to aesthetics. In this sense, the two proposals offer us a useful complementary, as well as a paradoxical convergence, due to their prodigious ability to identify not only the errors, exaggerations and blunders that occurred in the 20th century in terms of the emergence of political totalitarianisms (including Nazism, Fascism, Soviet Communism, etc.), but also the multiple armed conflicts and two world wars that took place (Firmenich, 2017).

They also provide tools for analyzing what constitutes the specific objective of this study and our core concerns for the $21^{\text {st }}$ century, which, as I understand, lend a certain urgency to our present reflections. The signs of Western decadence, especially in the United States, Europe and their respective spheres of influence on other continents, can no longer be ignored; the time has come to confront the project of a miniscule plutocracy that wants to take for itself the task of setting the direction and deciding the fate of Humanity as a whole. That will be the purpose of this brief presentation.

\section{Background and Theoretical Framework}

As the U.S. Supreme Court Justice Louis Brandeis, put it, "We may have democracy, or we may have wealth concentrated in the hands of a few, but we can't have both." 
First of all, we must lay the conceptual groundwork for pairing Marx and Kierkegaard. For this, it is worth resurrecting an article published in 1940 called "European Nihilism", published in Spanish in a book called El hombre en el centro de la historia. There, Löwith (the famous German student of Edmund Husserl and disciple of Martin Heidegger) reflected on Kierkegaard and Marx in the same way he did in his classic From Hegel to Nietzsche:

Among Hegel's disciples, Marx and Kierkegaard were the ones who most radically understood the inherent end of Hegelian philosophy. Thus, both posed the question of how to move beyond it. Their answer was: a new beginning can be achieved only by making a clean break with Hegel, not by continuing down the same road he already took to its end [...] When both realized that Hegelian mediation of reason with reality fell short precisely of reality, they proposed decision as an alternative to this mediation. Marx did it by calling for a new world order, while Kierkegaard turned his gaze toward the old Christian God. Both advocated dissolving the established order, although from there they went in opposite directions (Löwith, 1968 cited in Dip, 2011, pp. 2-3).

For this reason, Löwith sees them as thinkers who follow through on the objective of critiquing the bourgeois world in its capitalist (Marx) and Christian (Kierkegaard) dimensions. The same is stated by more recent analyzes, such as that of Rivera from the University of Santo Tomás, Colombia, who made us see that "it is essential to reread Marxist thought on the basis of the theology of liberation in order to contribute to the emancipation of human beings from everything that dehumanizes them "in the name of God" (2019, p. 110). Or, Aroosi, from the University of Toronto, who argued that there are fundamental underlying similarities between Kierkegaard and Marx "that allow us to read them in conversation so that we can properly extend Kierkegaard's work into the world of politics, because together they form the necessary ethical and political whole" (2018, p. 199).

However, not everyone agreed. Dip, for example, contended that Kierkegaard and Marx "do not represent a revolutionary break with $19^{\text {th }}$-century philosophy, as Löwith argues" (2011, p. 3). She gave a number of reasons,

While these thinkers can be seen "in conjunction" as philosophers who provided the terms for describing the age of "alienation" to which disenchantment with the bourgeois world leads, Marx's critique is "sociological," aimed at sparking emancipation; Kierkegaard's interest, on the other hand, is "psychological" and focuses on a critique that does not advocate political emancipation, but rather the affirmation of the bourgeoisie's moral conscience (Dip, 2011, p. 3).

The nuances that Dip included in her arguments provide substantial theoretical elements for building a framework capable of addressing the complexity of the problem with an interdisciplinary approach, and for rigorously characterizing its specificity in the $21^{\text {st }}$ century, with an eye to finding viable solutions for the future. She wrote, 
While complementarity can be seen in the starting point, i.e., the decision to oppose the assumption of identity between thought and reality as defended by Hegel, they disagreed when it came to diagnosing the crisis of the age. Young Marx calls it "alienation"; Kierkegaard uses the term "despair." This discrepancy in the diagnosis of the crisis has consequences in the solutions the two thinkers proposed [...] which share no common ground except for the starting point: the confrontation with Hegel, mediated in its origins by Schelling (Dip 2011, p. 3-4).

Nevertheless, we are convinced that the differences pointed out by Dip suggest ways to look at the phenomenon from different perspectives (political, economic, social, moral), with our attention focused on the crisis of inequality in the Western world today. In this sense, I believe there are fundamental points of convergence in the thought of Kierkegaard and Marx that can be useful for our purpose. As Pavanelli has written in the Oxfam GB:

Workers have known for years: most of the heralded benefits of globalization are reserved for a global elite who consider themselves untouchable. The myths of the current model of globalization are collapsing like a house of cards and with it the credibility of its proponents and trust in political institutions. Brazen corporate tax evasion, privatization, service cuts and decades of stagnating wages have not happened by accident. Urgent, radical action is needed to fund universal public services, decent work and redistribute wealth (Oxfam GB for Oxfam International, 2018, p. 7).

\section{Historical Materialism and Moral Dilemma}

Our leaders are aware of this, but instead of taking action to reduce wealth concentration and inequality, they are more interested in restricting democracy and freedom of expression for demanding a fairer society (Louis D. Brandeis Legacy Fund for Social Justice).

As we well know, neoliberalism and free trade in the West have been far from a resounding success over the last 40 years. Both have exacerbated unequal economic development among geographical regions, countries, and within countries, benefiting an ever more exclusive sliver of an elite. Some regions grow faster at the expense of others that do not grow proportionally or at the same time. As Ryder wrote in the Oxfam GB,

A majority of people want to live in far more equal societies. Reflecting these concerns, reducing inequality has rapidly risen up the agenda for global institutions and world leaders. This is reflected most prominently in the Sustainable Development Goals of the UN 2030 Agenda, where Goal 10 is a call to 'reduce inequality within and among countries' and Goal 8 calls for inclusive economic growth, full and productive employment and decent work for all (Oxfam GB for Oxfam International, 2018, p. 6). 
As the Spanish philosopher Recaséns Siches once observed subtly, Marx’s capital intention is his socialist aspiration; the economic theory of History is actually an odd accidental detour. Marx's non-negotiable, vital impetus, that which animated his entire existence - as well as his theoretical work, consciously or more likely unconsciously-was his insistence on a social transformation that would produce distributive justice, in a collectivist sense. In his time, the main criticism against socialism was that it represented a utopia, a gauzy, impossible dream. Marx wanted to lay a firm foundation for socialism, one that would stand up to the accusation of being an impractical ideal; he thus de-emphasized a prescriptive ought-to-be program and had the audacity to present it as inevitable, independent of human designs, i.e., a must-be development, based on an inexorable necessity that was bound to unfold in the next stage of economic evolution (Recaséns, 1965).

The relevance of Marx's thought in today's world is worth noting. As Firmenich (2017) mentioned, "we are facing a global systemic crisis (p. 555) [...] The crisis affects the systemic order of globalization, and highlights the failure of the dogma that markets (in this case, global markets) optimally regulate themselves (p. 567). [...] Neoliberal policies that seek to manage aggregate supply through structural reforms, fail because global markets are very, very far from perfectly competitive markets and because no market can be regulated optimally in the absence of political institutions" (p. 569).

In recent years, important private companies have merged and the trend toward monopolization among multinational companies has gotten stronger (at the expense of small and medium-sized companies). At the same time, market monopolization has also expanded, giving rise to an exorbitant concentration of capital: today, in the $21^{\text {st }}$ century, a few individuals and families have in effect manacled the political, economic and cultural spheres in the West, using intimidation in a way that diverges from the totalitarian and transpersonalist methods of the absolutism, the dictatorships and the statism of earlier centuries (particular the $19^{\text {th }}$ and $20^{\text {th }}$ ). Paradoxically, Russia, China and certain Asian and Scandinavian countries are working with different modalities and at different scales that do not conform to this pattern.

At this point in history we find ourselves facing a new kind of transpersonalism or totalitarianism, one the looks young, democratic and global. And yet, as with the others, human beings, are not seen as moral beings with dignity, as people with a singular mission to carry out on their own; on the contrary, they are used as mere tools or material for the achievement of goals that transcend their own existence, artifacts wielded as instruments for purposes that are unrelated to their personal lives. As such, they are valued not as subjects forming the substrate of the moral undertaking, but rather as merchandise that has a price, to the extent that they lend themselves for exploitation in pursuit of a transhuman project, for which individuality is of no consequence (Recaséns, 1965; see also, Müllerson, 2018, p. 925).

As it is stated in the Oxfam 2018 Briefing Paper:

Monopolies fuel excessive returns to owners and shareholders at the expense of the rest of the economy. The power of monopoly to generate extreme wealth is demonstrated by the fortune of Carlos Slim, the sixth richest man in the world. His fortune derives from an almost complete monopoly he was able to establish over fixed line, mobile and broadband communications services in Mexico. The OECD found that this monopoly has had significant negative effects for consumers and the economy (2018, p. 11). 
Kierkegaard's critical thinking in this regard is astonishing (and I refer especially to his works after Postscript, 2009b). Kierkegaard sought to rescue individuals from the veneration they professed for the idea of unfettered modernization nourished by a kind of selfish subjectivity championed by the Danish church of his day. "Christianity is like the age in which man decided to build the Kingdom of God on earth" (Thomas, 2012, p. 74).

He saw Christendom as "a culture religion," as "a profane messianism, in which man himself was scheduled to be the messiah," in an age that worshiped the "new gods" of progress, science, education, and humanity: These things gave us the Century of Progress, a century of progressive concern with the creature rather than the Creator (Thomas, 2012, p. 74-75).

The question arises here whether most of us in the West are not living a similar situation. Of course, the moral question is also aimed at the elites, especially when one considers their responsibility in the economic sphere,

Monopoly power is compounded by cronyism, the ability of powerful private interests to manipulate public policy to entrench existing monopolies and create new ones. Privatization deals, natural resources given away below fair value, corrupt public procurement, or tax exemptions and loopholes are all ways in which well-connected private interests can enrich themselves at the expense of the public (Oxfam GB for Oxfam International, 2018, p. 11).

If we admit that we are dealing with neo-totalitarianism, the question arises: What is the difference between traditional transpersonalism and the new version that has afflicted the Western world in recent years? Basically, that it is driven not by a State or a regional organization in particular, but by an elite that has concentrated in its hands the political, economic, social, media and cultural power of the Western world. The fortunes of the richest are often boosted by tax dodging - by rich individuals and by the corporations of which they are owners or shareholders. Using a global network of tax havens, as revealed in the Panama and Paradise Papers, the superrich are hiding at least $\$ 7.6$ trillion from the tax authorities. New analysis by economist Gabriel Zucman for this paper has shown that this means the top $1 \%$ is evading an estimated \$200bn in tax. Developing countries are losing at least $\$ 170 \mathrm{bn}$ each year in foregone tax revenues from corporations and the super-rich.

Even billionaires who have made their fortunes in competitive markets are often doing so by driving down the wages and conditions of workers, forcing countries into a suicidal race to the bottom on wages, labour rights and tax giveaways. At the same time the poorest children, and especially the poorest girls are condemned to die poor, as opportunities go to the children of richer families (Oxfam GB for Oxfam International, 2018, p. 11).

The collateral effects of this excessive concentration of capital and political power in the West has led to the monopolization of all manner of processes and required the implementation of ever more extreme and sophisticated measures. Economic rewards are increasingly concentrated 
at the top. While millions of ordinary workers remain on poverty wages, returns for shareholders and senior executives have gone through the roof (OECD iLibrary, 2012).

In South Africa, the top $10 \%$ of society receives half of all wage income, while the bottom $50 \%$ of the workforce receives just $12 \%$ of all wages. With just slightly more than one day of work, a CEO in the US earns the same as an ordinary worker makes during the whole year. Men are consistently the majority of the best-paid employees. On average, it takes just over four days for a CEO from the top five companies in the garment sector to earn what an ordinary Bangladeshi woman worker earns in her whole lifetime (Oxfam GB for Oxfam International, 2018, p. 11).

This underscores the utterly anti-Christian character of the transpersonalist ideology, which dismisses out of hand the individual's moral dignity and debases the human person to the condition of serf or slave, a mere means, thus repudiating the principles of Christian civilization and the norms of Western culture, that invite in the words of Pope Francis (2015) to a real encounter with Jesus, to co-responsibility with one's neighbor, to become one with all creation. Even to the extreme of dehumanization, which all of its strategies and projects would seem to point toward on a massive scale-population reduction, deindustrialization, ideological and media control, moral degradation, to name just a few of its manifestations. In another unprecedented peculiarity, it casually discards the framework of nation-states, including the abandonment of the role of nationalisms, of cultural particularities, the historical memory of peoples, social and family structures, and the dialogue that takes place at multilateral international forums. On the contrary, the transpersonalist agenda posits, or even exalts, the cognitive, socioeconomic and cultural inequalities of the world's different peoples and ethnic groups. It clutches at all costs at the ownership of resources; the control of science, technology, information media and the behavior of the majorities in order to guarantee accumulated privileges.

\section{Objectives and Strategies}

Indeed, discontinuities, insecurities and volatilities seem to be proliferating all the time and future changes seem to be accelerating towards us at a faster rate than we might have expected. (Christopher John Parry, Admiral of the Royal British Navy.

In this section we set out to analyze four of the vectors that were roughly sketched out in the previous paragraph, and that define or characterize $21^{\text {st }}$-century neo-totalitarianism. We will do this on the basis of a particularly thorough study of strategic trends prepared by the Development, Concepts and Doctrine Centre of the UK's Ministry of Defence. This is a document that, despite having been written as input for that country's defense policy, also serves as a reliable source of information for our purposes, inasmuch as it offers an interdisciplinary forecast, and considers crucial variables that are often ignored or overlooked in academic diagnoses and serious estimations of the future. By way of contrast, some quotes taken from the latest OXFAM report (2018) are included, along with some from the report published in 2014. 


\section{Deindustrialization}

We will start with the strategies aimed at weakening the pace of economic growth and assuring the destruction, over the medium and long terms, of the industrial model. There is a clear intention to achieve 0 (zero) growth and weaken the economic and political power of Nation-states as a whole, especially of the peripheral countries that supply raw materials and labor (Robinson, 2014; Estulin, 2013). The world economy is likely to continue growing at an annual rate of 2-3\% at least until 2020, accompanied by overall improvements in well-being, with more spectacular growth in the Asia-Pacific region. The growth, however, will be uneven, varying among different regions over time. Sub-Saharan Africa will likely lag behind other regions due to environmental factors and political and demographic challenges related to the region's endemic corruption (Development, Concepts and Doctrine Centre (DCDC), 2007). If the pace of growth does not slow down, the competition for resources of all kinds will only intensify. The developed and developing economies will look for political and economic partnerships with states to guarantee their supplies (Development, Concepts and Doctrine Centre (DCDC), 2007).

It is worth recalling the procedures for bringing about this deindustrialization: First the financial power of the Nation-state is restricted to guaranteeing financial operations and securing the balance of payments. Then limits are set on the State's productive capacity to use available financial resources and generate needed changes, such as reactivating the economy, creating jobs and fostering a fairer and more balanced development to the benefit of the population. Next, financial rules are loosened, speculation is encouraged, and resources are siphoned off to so-called tax havens to the detriment of the State's ability to raise revenue and fulfill its economic, social and historical obligations to its populations. Finally, the State's political power and sovereignty are undermined, in favor of the interests and decisions of the tiny caste of people who control the main means of production (Robinson, 2014).

Globalization and deregulation are commonly thought to be inextricable (Woofter, 2019). This is erroneous. The assumption is that the more an economy is globalized and integrated, the more it becomes deregulated, and it is not possible to have one without the other. Countries like South Korea, or more recently Brazil, have managed to reduce inequality while engaging in the global economy, and they have been able to do this in part using significant regulation of many aspects of their economies.

Markets and economic integration can be an important engine for growth and prosperity. But both need careful management and regulation in the interests of everyone, so that the proceeds of growth are distributed fairly. Left unchecked they threaten our democracies and the ability to create more equal societies. A new vision of globalization is needed (Oxfam GB for Oxfam International, 2018, p. 11).

If one takes a close look, deregulation per se has meant nothing other than the systemic subordination of peripheral countries: their chronic dependence on developed countries, foreign capital and large transnationals. Elites have succeeded in taking control of spaces, natural resources and productive processes, which has led to an accelerated dismantling of local production capacity, the gradual automation of industrial processes, the impoverishment of large sections of the population, chronic unemployment, the multiplication of informal activities for the sake of survival, etc. 
It is hard to find a political or business leader these days who is not saying they are worried about inequality. Yet actions, not words, are what count, and here most of our leaders are lacking. Indeed, many are actively promoting policies that can increase inequality. [...] Development Finance International has compiled a detailed index of 152 governments' actions to tackle inequality, and the majority are shamefully failing to do nearly enough to close the gap (Oxfam GB for Oxfam International, 2018, p. 8).

\section{Population Decline}

It is worth asking about the threats that elites today perceive in population growth. According to the study of strategic trends cited above, sustained population growth, aggressive economic competition and an increase in consumption, together with rapid modernization and urbanization, give rise to intensive exploitation and pressure on resources of all kinds. These tendencies will only get worse when the consequences of climate change and other environmental changes kick in (van Kessel, 2020). As a result, the availability and flows of energy, water and food will become critical problems, along with the potential for fluctuations and imbalances in both production and distribution at the global, regional and local levels (Development, Concepts and Doctrine Centre (DCDC), 2007).

The balance between economically inactive and active members of society will alter significantly and there will be sharp age differentials between the ageing First World and the youthful Third World. Overall, the global population is ageing and cyclical unemployment will become more widespread, especially among the growing urban poor, who are likely to make up 25\% of the global population. Marked age imbalances, between regions and countries, together with gender imbalances, will accentuate and exacerbate existing tensions, both regionally and internationally (Development, Concepts and Doctrine Centre (DCDC), 2007, p. 8).

It is estimated that by $2035,60 \%$ of the world's population will live in urban areas. There will be significant growth in unplanned urban settlements, which will increase the cost of resources and environmental impacts. In some cases, rapid, uncontrolled development will challenge the ability to grow (Development, Concepts and Doctrine Centre (DCDC), 2007).

For these reasons, population decline has become a high-priority strategy. Obviously, the go-to strategies are the traditional ones: propagation of war, low-intensity warfare, armed conflicts, support for rebel groups and resistance movements, arms manufacture and trafficking, forced disappearance, etc. (Robinson, 2014). Then there is the development, production and proliferation of chemical, biological, radiological and nuclear weapons, and access to the technology that enables the production and distribution of chemical and biological products. It is likely that radiological and nuclear weapons will increase (QBRN). According to the study of strategic tendencies,

There will be an increased risk of humanitarian catastrophe in the most vulnerable regions, caused by a mixture of climate change, resource pressures, uneven distribution of wealth, the effect of disease and the failure of authorities to cope with population growth and urbanization. 
Migration and urbanization, within countries and across regions, will increase pressure on infrastructure and governance and may destabilize existing communities. [...] Authorities will be challenged by changing demographics, in particular the impact of an increasing youth population in some developing regions and countries - poor employment prospects and unfulfilled expectations may lead to vulnerability to populist and other extreme messages (Development, Concepts and Doctrine Centre (DCDC), 2007, p. 6).

Collaterally, the emergence of new diseases and pests is being promoted, along with the genetic modification of seeds, the development of the agro-chemical industry and pesticides. The monopolization of agriculture and the control of the food and pharmaceutical industries are faits accomplis.

Finally, it should not be overlooked that in peripheral regions with market-valuable natural resources, fear is being induced in urban areas, terror in the countryside, and emigration in regions coveted by transnational capital.

\section{Weakening and Phasing Out the Nation-State}

According to the study of strategic tendencies, even though citizenship and physical security continue being important in the short term, people's loyalty to the State and its institutions will most likely fade away in the future in some countries, or at least become more fleeting and conditional, as globalization wears down national distinctions. On this point the study's assessment proves to be somewhat ambiguous or subordinated to ideology,

- Nationhood and ethnicity in certain countries will continue to influence human behavior and international relations.

- Diaspora communities and their networks will be dynamic and unpredictable features of the political, demographic and economic aspects of globalization.

- Physical and cultural origin will continue to be significant to identity, but will be employed increasingly selectively, based on their utility in context and in relation to personal interest.

- Communities will increasingly form around the pursuit of common interests and may dissolve rapidly when they are no longer relevant (Development, Concepts and Doctrine Centre (DCDC), 2007, p. 10).

The study also forecasts certain geographical areas ("including failed states, provinces or cities, and other population groupings") that will not be subject to effective governance and the rule of law. It predicts that weak states, even as they continue to claim rights of sovereignty, will subsist through illegal trade and organized criminal activity, while others will not be able to curb instability and contain the consequences of transnational pressure. It points out that the risks associated with these ungoverned and/or poorly governed places ("including endemic criminal activity, the basing of terrorists, irregular activity and conflict") are likely to increase and add to the complexity, and by extension, to the burdens of maintaining the integrity of the international system (Development, Concepts and Doctrine Centre (DCDC), 2007).

From the perspective of the OXFAM 2014 Briefing Paper, however, all of this is unfounded and relative. The weakening of the Nation-state does not derive from the inevitable waning of the cultural mentality and idiosyncrasy of distinct peoples under pressure from globalization, but from 
the hijacking of political and democratic processes by economic elites (Estulin, 2015), looking for a totalizing and transpersonal impact that benefits the few. As the study asserts, these processes have remarkable repercussions that affect rich and poor countries alike:

The impact of political capture is striking. Rich and poor countries alike are affected. Financial deregulation, skewed tax systems and rules facilitating evasion, austerity economics, policies that disproportionately harm women, and captured oil and mineral revenues are all examples given in this paper. The short cases included are each intended to offer a sense of how political capture produces ill-gotten wealth, which perpetuates economic inequality (Oxfam GB for Oxfam International, 2014, p. 3).

Consequently, the weakening of the Nation-state is foreseen, tending toward its eventual disappearance, especially in those sovereign States that are capable of producing their own food, still maintain control over most of their strategic resources and seek equality and progress for their population, e.g., countries such as Iran, Iraq, Syria, Lebanon in the Middle East; Egypt and Libya in Africa; or Venezuela in Latin America, etc.

From a political viewpoint, the elites (exogenous and/or endogenous) in these places discretely promote chaos, dispossession, civil war, violence, terrorism, emigration; in the economic sphere, as discussed above, they encourage zero growth, impoverishment, hunger, despair, internal displacement toward economically irrelevant regions, etc. In the cultural sphere, they encourage the development of cosmopolitan communities alienated from the History and customs of their countries of origin, thus opening the door to the manipulation of nationalist ideas and customs.

The study of strategic tendencies hints at their machinations in veiled terms:

- Transnational pressures, competition and globalization will challenge the robustness and resilience of governance and social mechanisms at every level.

- New collaborative institutions, philosophies and mechanisms will be required to cope with complex, inter-connected global and regional problems.

- The exercise of national sovereignty will increasingly be expressed in support of collective international action, but regimes and polities will continue to act to protect their citizens and sustain their vital interests and stability.

- Responsibility for international arrangements will lie with the national parties to them; the emergence of a new supra-national sovereign power is unlikely (Development, Concepts and Doctrine Centre (DCDC), 2007, p. 14).

\section{Derationalization, Psychic Control Techniques and Changes in Cultural Values}

Another strategy that models and characterizes the transpersonalism of contemporary elites in their campaign to reinforce the totalitarian status quo and impose their viewpoints and interests is the amplification and expansion of the monopolization of knowledge, science and technology with an eye to setting the agenda and future direction of these pursuits. The aim is to strengthen the elites' long-term position in terms of the concentration of power, wealth and social control (Robinson, 2014).

Priority is naturally given to the selective development of fields of knowledge that directly or indirectly foster evolutionism, artificial intelligence, nanotechnology, robotics, automation, etc. 
The ideological and psychosocial control of the population is reinforced through education, indoctrination and the gradual degradation of human values, by means of behaviorist techniques and information-retrieval technologies, inasmuch as

The pervasiveness of ICT will enable more people to access and exploit increasingly interconnected and sophisticated information systems. For example, it is estimated that $20 \%$ of the African population will subscribe to internet-enabled mobile phones by 2010. The Internet and associated technologies, together with digitized portable communications, will increasingly become the means by which a rapidly expanding array of audio, visual and written information and entertainment products is distributed (Development, Concepts and Doctrine Centre (DCDC), 2007, p. 11).

Although the advances in ICTs and the latest mass transit systems might enhance connectivity among ethnic / nationalist diasporas and their communities of origin, they will tend to discourage the genuine cultural integration and assimilation of peoples and communities by enabling the existence of autonomous "virtual" intercontinental communities that will not always be in tune with the interests and aspirations of their countries of origin, thus favoring the homogenization and uniformity of consciousness, thought and ideas.

It is assumed that the volume of information will serve as a counterweight to decisionmaking processes based on 'orderly' knowledge management and rigid hierarchical organizations. Technological monitoring processes and intelligence agencies will have to contend with the speed and diversity of innovations, which will likely "emerge" with greater frequency. The rate of technological innovation will reduce the time available for the assimilation and control of 'culture,' which will increase the chances of results that the elites would rather avoid, as they look for effective mechanisms for social control in order to prevent the international transmission of social risks, including intercommunal violence, terrorism and transnational crime, especially illicit trafficking and trade (Estulin, 2015).

The assumption is that scientific and technological innovation, research and development will originate from international sources other than the traditional ones (developed countries) and therefore that the regulation and control of new technologies will prove to be more elusive for the elites. In those cases, the exploitation of the sources can lead to results that are catastrophic for elites, especially developments associated with nanotechnology, biotechnology and weapons systems. There might be "unintended" consequences, for example, "runaway" nanotechnology or biotechnology aimed at the development and use of directed energy or electromagnetic-pulse weapons (Development, Concepts and Doctrine Centre (DCDC), 2007).

As for changes in values, the study expects secularism and materialism to grow in importance in an ever more competitive and interconnected world, especially in developing countries, since these tendencies toward depersonalization and dehumanization are already firmly rooted in more developed regions. Meanwhile, cultural mixing, the pace of change and a rapid confluence of modern and traditional ideas are foreseen in the medium term, consolidating the trend toward moral relativism and increasingly pragmatic values.

However, the DCDC Strategic Programme (2007) predicted that this axiological trend will not manifest itself evenly: it will generate diverse responses, especially among more traditionalminded minorities and communities, who will seek refuge in orthodox belief systems and different political ideologies. 
One final change in values is emerging, related to the family. The same study points out that family arrangements will become more economically and socially diverse and fluid, shaped by culture, interests and circumstances, and characterized by the combination of biological and functional relations. However, traditional structures are likely to persist and formal marriage is likely to remain popular, even as their character and resilience are determined by economic conditions and prevailing cultural values.

\section{Discussion}

The prospective study that we have reviewed in this section and the analytical efforts made by OXFAM to diagnose what is happening today on a global scale, fully justify the main objective of our analysis, which has tried to bring to the center of the academic discussion the approaches that from different disciplinary angles have made on the subject some thinkers and analysts of the social sciences and humanities (among others, Estulin, 2015; Firmenich, 2017; Müllerson, 2018; Fróes, et.al., 2019). Of course, we built the conceptual scaffolding on rigorous and reliable contrasting bases, having detected that the speeches of two thinkers of the stature of Søren Kierkegaard and Karl Marx coincided at core points (Dip, 2011; Thomas, 2012; Aroosi, 2018; Dorrien, 2018; Rivera, 2019). This led us to critically review, reflect and deduce the enormous socio-economic disparities that the neoliberal model has produced in recent decades, and the foreseeable consequences that the enormous concentration of power and wealth may have for the human species in the future, if there are no significant changes in the system.

\section{Conclusions}

Hundred and twenty-four million people in 51 countries need urgent help to stay alive, warned a report prepared by the United National Food and Agriculture Organization (FAO), the European Union (EU) and other international organizations. Anonymous note from Afp (La Jornada, 2018, p. 36).

The attempt to marshal two such dissimilar thinkers as Karl Marx and Søren Kierkegaard has borne fruit. It could have potential as an analytical tool for the future. It has enabled us to look more deeply into the sources of their discontent, but also at their concurrences, as we realize that in the $21^{\text {st }}$ century, most of us who live in the countries and regions of the so-called Western world are not free. We live in ostensibly democratic societies, but find ourselves trapped in a neototalitarian or transpersonal system unlike any that has come before, enabled by an exorbitant concentration of wealth and political power in the hands of a tiny elite shamelessly eager to determine the world's fate (and even to become a permanent kleptocracy). This phenomenon has no historical precedent, which is why the intercultural dialogue between Marx and Kierkegaard in this paper has been a worthwhile and necessary undertaking, a conversation that calls for serious balance and prudence. Marx advocates equality at a time when the world has hit bottom in this regard:

Last year saw the biggest increase in the number of billionaires in history, with one more billionaire every two days. There are now 2,043 dollar billionaires worldwide. Nine out of 10 are men. Billionaires also saw a huge increase in their wealth. This increase was enough to end extreme 
poverty seven times over. $82 \%$ of all of the growth in global wealth in the last year went to the top $1 \%$, whereas the bottom $50 \%$ saw no increase at all. Living wages and decent work for the world's workers are fundamental to ending today's inequality crisis. All over the world, our economy of the $1 \%$ is built on the backs of low paid workers, often women, who are paid poverty wages and denied basic rights (Oxfam GB for Oxfam International, 2018, p. 9).

Kierkegaard, on the other hand, asserts that individuals in modern "mass society" lack "passion" and individuality, that the destruction of local communities and the growing sameness and uniformity of human social experience is blurring differences, and that these trends are occurring not only at the regional and national levels, but worldwide (Krynski, 2019; Sayers, 2011).

Paradoxically, Marx, although he also describes the increasing scale of modern social relations, sees them as the inherent effect of the expansion of capital. His understanding is different because it grows out of his critique of capitalism. Marx did not feel that the developments leading toward "mass society" identified by his Danish contemporary were all bad in terms of their effects on humanity (Sayers, 2011),

Globalization and the erasure of local differences, the equalisation of social experience, the growth of mass education and mass culture, even the allpervasive cash-nexus and alienation brought about by capitalism - none of these tendencies is purely negative or destructive in its impact on human life. As much as these developments destroy local communities, and fragment, 'level', homogenise and alienate people, at the same time they also create new and wider relations and connections between people; and in so doing they open up opportunities for self-development and cultivation previously available only to a tiny elite. To be sure, these forms of activity often take commodified and commercial forms which limit their human value. Nevertheless, any adequate account of the character of modern society must register both sides of the case, the positive as well as the negative (Sayers, 2011, p. 12).

Returning to Kierkegaard, as the American theologian and philosopher Owen Clark Thomas points out,

Kierkegaard sought to rescue the individual from the illusion that his spirit was being improved by his participation in the modernization of Denmark, which was based on the philosophical "principle of individualism" developed by Hobbes, Locke, John Stuart Mill, and Adam Smith. For Kierkegaard this development nurtured an "egotistical mode of subjectivity" [...] So, he viewed his task as the "Socratic one of awakening his reader from three illusions: his ignorance about himself as a being who egotistically loves himself and desires to achieve a publicly recognizable and valued identity; his self-deception that he is a Christian; and his belief that Denmark is a Christian nation (2012, p. 74-75). 
As we have seen, both Marx and Kierkegaard place powerful and convergent politicalsocial and moral options before the Western world today. Even though existentialism rejects the possibility of moral absolutes because they would place universal principles above individuals' concrete needs, it does offer in their place a life free of self-deception, a life that embraces the finiteness and vulnerability of the human situation and recognizes that individual actions always have an impact on the lives of others (Aho, 2014; Soyer, 2019).

As it is indicated in the OXFAM Briefing Paper, January 2018, it is hard to find a political or business leader these days who is not saying they are worried about inequality. Yet actions, not words, are what count, and here most of our leaders are lacking. In fact, most of them actively promote policies that contribute to growing inequality. As Napoleón Gómez writes, opulence and cynicism are today ever more glaring in the eyes of those who have little or nothing. The government's favorites and all those who benefit from inequality do not want to see countries make changes; they want things to stay the same. In their eyes, those who promote change are advocates of backwardness and enemies of stability. Transformations are to be feared, because they threaten their comforts and privileges. Innovators are not just their political adversaries: they are mortal foes to be destroyed or eliminated. This stance has become a downright obsession, distorting their thinking to such a degree that they have lost all sense of social responsibility (2018).

This represents a historical commitment and a moral imperative that the West can no longer overlook, above all when there are States and cultures that have resisted this logic. China is one example. While Marxism has served to introduce and enable modernity in China, albeit in a rather forced way, as Xilin, Yang Huilin and other Chinese philosophers have recently suggested (Jeffrey, 2011), it has proven to be less effective in simultaneously making a critique of modernity, since Marxism is built, at least at first glance, upon materialist, not transcendent assumptions. Paradoxically, Christianity has come to rectify this deficiency, and might just serve as the bridge or point of intersection for linking the reflections of Marx and Kierkegaard that we have invoked in this essay.

As Jeffrey recalls, it was the eminent classical Chinese philosopher Liu Xiaofeng, simultaneously Marxist and Christian, who upon surveying this genealogy a half century after the revolution of 1949, insightfully observed that "the translations of Marx's works and of other Western classics (of philosophy and literature) introduced China to a culture of humanism that included Christian thinking" (2011, p. 978). Consequently,

Between the medium and this message there has been an unforeseen and creative synergy, now blossoming in many Chinese universities, in which aspects of both Christianity and Marxism are unconsciously but dynamically juxtaposed, creating there for the first time, perhaps, conditions for the emergence of some features elsewhere found only in the earlier Catholic and Christian history of the Western university. In ways that one hopes Alasdair MacIntyre would at least appreciate, if not entirely approve, the movement from idealistic Marxism, through its disappointments, to a renewed search for truth and the common good in the Chinese academic world in some measure mirrors his own personal intellectual development, from a principled earlier Marxist idealism to his mature role as one of the best of contemporary spokesmen for a genuinely Catholic conception of the university. But what his argument and concise resumé of the relationship between theology and the intellectual life of the university make clear, is that no university can remain credibly open to a 
right relationship between the life of the mind and pursuit of the common good that does not maintain and advance the prominence of theology and theological reflection among the disciplines (Jeffrey, 2011, p. 978).

\section{References}

Aho, K. (2014). Existentialism: An Introduction. Polity Press.

Aroosi, J. (2018). The Ethical Necessity of Politics: Why Kierkegaard Needs Marx. Toronto Journal of Theology, 34(2), 199-212.

Development, Concepts and Doctrine Centre (DCDC). (2007). DCDC Global Strategic Trends Programme.

http://www.mod.uk/DefenceInternet/AboutDefence/Organisation/AgenciesOrganisations/ DCDC.

Dip, P. C. (2011). Kierkegaard y Marx en la filosofía de la historia de Karl Löwith. Memoria Académica de la VIII Jornadas de Investigación en Filosofía, 1-15. http://jornadasfilo.fahce.unlp.edu.ar/viii-jornadas-2011

Dorrien, G. (2018). Religious Socialism, Paul Tillich, and the Abyss of Estrangement. Social Research, 85(2), 428-452.

Dussel, E. (2015). Dossier: San Romero de América. La religión como critica a la opresión. La figura mesiánica de Oscar Arnulfo Romero (1917-1980). Tareas, (151), 113-117.

Dussel, E. (2016, November 15). La importancia de entender los mitos [Video]. YouTube. https://www.youtube.com/watch?v=-y1f1TeI7rg

Estulin, D. (2013). El club de los inmortales. Ediciones B.

Estulin, D. (2015). Fuera de control. Editorial Planeta.

Firmenich, M. E. (2017). The Systemic Global Crisis: A Long Cycles Approach with a Political Economic Perspective. Estudios de Economía Aplicada, 35(3), 555-574.

Francisco (The Pope). (2015). Laudato si'. Santa Sede. https://tinyurl.com/ncnkttm.

Fróes de Borja Reis, C.; Santana Barbosa, M. \& Cardoso, F. G. (2019). The South's Thoughts on Development: Links Between Latin America and Africa. Revista de Economía Mundial, (52), 191-216.

Gómez, U. N. (2018). La decadencia moral de un gobierno. La Jornada. http://www.jornada.unam.mx/2018/04/05/opinion/018a1pol.

Jeffrey, D. L. (2011). Marxist and Christian: MacIntyre and the Postmodern University. Nova et Vetera, 9(4), 967-989.

Kierkegaard, S. (2009a). Ejercitación del cristianismo. Editorial Trotta.

Kierkegaard, S. (2009b). Concluding Unscientific Postscript. Cambridge University Press.

Krynski, A. (2019). In a State of Fragility: The Compromised Dignity of Communities, Indignation, and the Incapacitation of Public Education. Journal of Culture and Values in Education, 2(3), 1-24. https://doi.org/10.46303/jcve.03.02.1

Marx, K. (1981). El capital, Crítica de la economía política. El proceso global de la producción capitalista en su conjunto. Siglo XXI editores.

Müllerson, R. (2018). Human Rights Are Neither Universal Nor Natural. Chinese Journal of International Law, 925-942.

OECD iLibrary. (2012). OECD Employment Outlook 2012. http://www.oecdilibrary.org/employment/oecd-employment-outlook-2012_empl_outlook2012-en/

Oxfam GB for Oxfam International. (2014). Working for the Few. Political capture and economic inequality. OXFAM Briefing Paper. Oxfam GB for Oxfam International. 
Oxfam GB for Oxfam International. (2018). Reward Work, not Wealth. OXFAM Briefing Paper. Oxfam GB for Oxfam International.

Recaséns Siches, L. (1965). Tratado general de Filosofía del Derecho. Editorial Porrúa.

Rivera Gómez, A. F. (2019). Marx, el cristianismo y la violencia de lo sagrado. Hacia una anamnesis de la teología de la liberación. Cuadernos de Filosofía Latinoamericana, 40(121), 109-129.

Robinson, A. (2014). Un reportero en la montaña mágica. Cómo la élite económica de Davos hundió el mundo. Paidós.

Sayers, S. (2011). The Concept of Alienation. Hegelian Themes in Modern Social Thought. Marx and Alienation, 11-13.

Soyer, G. (2019). Urie Bronfenbrenner: The Ecology of Human Development Book Review. Journal of Culture and Values in Education,2(2), 77-80. https://doi.org/10.46303/jcve.02.02.6

Thomas, O. C. (2012). Kierkegaard's Attack upon Christendom, and the Episcopal Church. Anglican Theological Review, 94(1), 59-78.

van Kessel, C. (2020). Teaching the Climate Crisis: Existential Considerations. Journal of Curriculum Studies Research, 2(1), 129-145. https://doi.org/10.46303/jcsr.02.01.8

Woofter, S. (2019). Book Review: Building Equity: Policies and Practices to Empower All Learners. American Journal of Qualitative Research, 3(1), 136-139. https://doi.org/10.29333/ajqr/5815

\section{Notes On Contributors}

Humberto Ortega-Villaseñor is a Mexican senior full time professor and a research fellow at the University of Guadalajara since 1989. After receiving his Bachelor of Law degree in 1975 at the National Autonomous University of Mexico (UNAM), Villaseñor continued his Master's studies in Great Britain (London University) and finished his PhD at UNAM in Mexico (1982). He has published three books and many articles. His focus of interest covers various fields of social sciences and humanities related primarly to philosophy, communication, art and culture. As a member of the Department of Literary Studies since 2003, he hasconcetrated his efforts in investigating the links between plastic and literary creativity from a scientific perspective, deepening in the anticipatory impact those links may have to the world of science, technology and culture. As a visual artist, he has numerous individual exhibitions in Mexico, the United States and Europe since 1975. Currently, he inroads also in the study of links between words and moving images. He is a member of the National System of Researchers, CONACYT (Mexico), and the Academic Board of the PhD Program in Humanities. 